Karolina M. Szymorek-Chachuta*

\title{
CONCLUDING AN EMPLOYMENT AGREEMENT VIA ELECTRONIC MEDIA
}

\section{Introductory remarks}

Pursuant to Art. 29 section $2^{1}$ of the Labour Code ${ }^{2}$ employment contract is concluded in writing. If concluded otherwise, the employer must, at the latest on the employment commencement date, confirm to the employee in writing the arrangements concerning the parties to the contract, type of work and its terms and conditions.

Hence, employment contract should in principle be concluded in writing, however, non-abidance by this form does not cause an employment contract concluded otherwise than in a written form to become invalid or ineffective. This position is grounded both in the doctrine and judicature ${ }^{3}$. An employment contract concluded otherwise than in writing is, therefore, valid, effective, binding on both parties, and constitutes an employment relationship ${ }^{4}$.

* Ph.D. Student of Department of Labour Law, University of Lodz, Faculty of Law and Administration, Labour Law Chair, 90-232 Lodz, Kopcińskiego 8/12, Poland.

1 Article 29 section 2 of the Labour Code: An employment contract must be made in writing. If an employment contracts is not made in written form then the employer must, at the latest on the date when the employee commences work, provide the employee with a written statement of the settlements in relations to the parties to the contract, the type of the contract as well as its conditions.

2 Labour Code Act dated 26 June 1974, Journal of Laws of 1998, No. 21, item 94 uniform text with as amended.

3 Judgement of the Supreme Court dated 6.10.1976, I PRN 66/76, Legalis; judgement of the Supreme Court dated 20.9.1977, I PR 67/77, Legalis; judgement of the Supreme Court dated 8.10.1987, I PRN 47/87, Sł.Prac. 1988, No. 3, p. 29.

${ }_{4}$ A. M. Świątkowski, Komentarz aktualizowany do art. 29 Kodeksu pracy, [in:] K. Jaśkowski, E. Maniewska, Komentarz aktualizowany do ustawy z dnia 26 czerwca 1974 r. Kodeks pracy (Dz.U.98.21.94), Lex, No. 156677. 
At this point it needs to be said that the multiplicity of electronic media and the ensuing diversity of the forms of statements that can be made by parties to the prospective employment relationship entail a more exhaustive study of the issue of concluding employment contracts through electronic media.

First of all, employment relationship is established upon mutual intent being declared by both the employer and the employee. It is, therefore, reasonable to regulate that non-abidance by the written form of the declaration made cannot cancel the legal relationship itself, as it does not rely on the form in which the declaration is made. Given that the basic rule of law is the freedom of employment contract $^{5}$, whereby employment relationship is only conditional upon mutual intent of the parties, and the parties are also free to choose the manner and form of making such mutual declarations, as well as the basis and terms of employment ${ }^{6}$.

Furthermore, the Labour Code does not regulate the form in which a declaration of intent has to be made, or the manner of concluding employment contracts, or the consequences of not applying the given form, hence, pursuant to Art. $300^{7}$ of the Labour Code, these matters are governed accordingly by the applicable provisions of the Civil Code ${ }^{8}$, unless these contravene the provisions of labour law.

\section{Provision of art. 29 section 2 - "written" form}

Art. 29 section 2 of the Labour Code only requires that employment contract must be concluded "in writing". It is not clear, however, whether this "written" form may be understood otherwise than the conventional written form within the Civil Code regulations. In my opinion, the "written" form within labour law is not the conventional written form within the Civil Code regulations.

Given that the provision of Art. 29 section 2 of the Labour Code indicates a "written" form, it could be assumed that reasonable lawmakers have applied this term for a purpose. The term "written form", on the grounds of the Labour Code, is elucidated by T. Wrocławska as including handwritten, digital, printed or electronic form". To my mind this "written form" within Art. 29 section 2 of the Labour Code approaches a declaration of intent in the objective meaning, i.e. as a result of an act by the declarant, which result takes on the form of a certain

${ }_{5}^{5}$ L. Florek, Ksztattowanie stosunku pracy przez ustawe i umowe, [in:] L. Florek, Ustawa i umowa w prawie pracy, Oficyna 2009, Lex, No.108050.

${ }_{6}$ More information: Z. Góral, O kodeksowym katalogu zasad indywidualnego prawa pracy, Warszawa 2011, p. 117 et seq.

7 Article 300 of the Labour Code: In cases not regulated by the provisions of labour law, the provisions of the Civil Code apply accordingly to an employment relationship, provided they are not contrary to the principles of labour law.

8 Civil Code of 23 April 1964, Journal of Acts 1964, No. 16. item 93 uniform text as amended.

9 T. Wrocławska, Problemy dopuszczalności rozwiąywania umów o pracę za pomoca środków komunikowania się na odległość - artykuł dyskusyjny, PiZS 2006, No. 11, p. 13. 
substrate of a sign (e.g. a document in written or electronic form) that carries specific thoughts expressed by the declarant ${ }^{10}$. Concluding an employment contract "in writing", therefore, means that it is necessary to record it in a written form containing the declaration of intent of both parties to the prospective employment contract ${ }^{11}$, however, not necessarily in the form of a document (sheet of paper) signed by both parties to the employment contract.

Such interpretation of the regulation is closer to the contemporary process in which electronic documents and declarations made through electronic media are increasingly ubiquitous. Also, one cannot ignore the fact that since the time when the provision within Art. 29 section 2 of the Labour Code was enacted, technology has developed to the extent that it does affect labour law regulations and its interpretation ${ }^{12}$. For a long time now literature has brought to attention the dynamic development of labour law and its relation to the ever changing economic life ${ }^{13}$. It seems that the interpretation of the word "written" within Art. 29 section 2 of the Labour Code should adapt to such changes. The more so that the form of the employment contract is not solely reserved for evidentiary purposes. The option of applying provisions restricting the admissibility of witness and testimonial evidence in labour law and social security proceedings has been expressly excluded in terms of Art. 473 of the Civil Procedures Code ${ }^{14}$.

\section{Concluding employment contracts}

It goes without saying that certain inconsistency of the legislature, who in the first sentence of the provision of Art. 29 section 2 of the Labour Code use the term "in writing" and in the next sentence the term "written form" induces one to assume that employment contract should be concluded in the "conventional written form". This position is also expressed in most of the doctrine ${ }^{15}$. The Supreme

10 A. Janiak, Komentarz do art. 60 Kodeksu cywilnego, [in:] A. Kidyba (ed.), Z. Gawlik, A. Janiak, A. Jedliński, K. Kopaczyńska-Pieczniak, E. Niezbecka, T. Sokołowski, Kodeks cywilny. Komentarz. Tom I. Część ogólna, WKP 2012, Lex, No. 128098 and its literature.

${ }_{11}$ M. Zieleniecki, Komentarz do art. 29 Kodeksu pracy, [in:] U. Jackowiak, M. Piankowski, J. Stelina, W. Uziak, A. Wypych-Żywicka, M. Zieleniecki, Kodeks pracy z komentarzem, Fun.Gosp. 2004, Lex, No. 66057.

12 See: B. Kaczmarek, Nowe technologie, nowe możliwości-nowoczesne formy komunikowania się sadu i stron procesu cywilnego, a także sąów między soba-uwagi na tle aktualnych przepisów, [in:] J. Gołaczyński, Prawo Mediów Elektronicznych, "Legalis" 2008, No. 8.

13 T. Wrocławska, op. cit., p. 13.

14 Code of Civil Procedure as of 17 November 1964, Journal of Laws of 2014, item 101, uniform text as amended.

${ }_{15}$ M. Zieleniecki, op. cit; A. M. Świątkowski, op. cit; M. Tomaszewska, Komentarz do art. 29 Kodeksu pracy, [in:] K. W. Baran (ed.), B. Ćwiertniak, S. Driczinski, Z. Góral, A. Kosut, W. Perdeus, J. Piątkowski, M. Skąpski, M. Tomaszewska, M. Włodarczyk, T. Wyka, Kodeks pracy. Komentarz, WKP 2012, Lex, No. 126484. 
Court, too, has indicated that the "written form" under the labour law provisions must meet the conditions within Art. $78^{16}$ of the Civil Code ${ }^{17}$.

In order to conclude an employment contract in the conventional form, as described in Art. 78 of the Civil Code, it suffices to exchange the documents that contain the declarations of intent of the employee and the employer, both signed by one of the parties, or the documents each of which contains the declaration of intent signed by one of the parties. Therefore, the minimum requirement to abide by the written form of employment contract is to sign the document (employment contract) or documents, should the documents be exchanged in the manner specified in the second sentence of the provision of Art. 78 of the Civil Code ${ }^{18}$.

Placing a safe electronic signature - by means of a qualified certificate - under the declaration of intent in electronic form is equivalent to making such declaration in the conventional written form (Art. 78 section 2 of the Civil Code). This is not the case with "check box" declarations, e.g. available on websites, and signed e-mails, where, pursuant to the Act on Electronic Signatures, such signature is an "ordinary" electronic signature.

Importantly, in terms of Art. $60^{19}$ of the Civil Code, applied accordingly on the grounds of labour law, subject to the exceptions provided in the act, a person with legal capacity may express the intent by any conduct that sufficiently communicates that intent, also in electronic form. The provisions of Art. 60 of the Civil Code, as well as Art. 8 of the Act on Electronic Signatures ${ }^{20}$ (hereinafter referred to as A.E.S.) refer to all declarations of intent made electronically with any kind of electronic signature, including the one which is not the electronic equivalent of personal signature. Using an electronic form is only one option of expressing intent. It is not a competitive form separate from the already existing written form $^{21}$. A candidate may express the intent to establish employment relationship

${ }_{16}$ Article 78 of the Civil Code: section 1 In order to observe standard written form for a legal act, it is sufficient to set a handwritten signature to a document containing a declaration of intent. In order to execute a contract, it is sufficient to exchange documents containing declarations of intent, each of which is signed by one of the parties, or documents, each of which contains a declaration of intent of one party and is signed by this party. section 2 A declaration of intent made electronically and bearing a secure electronic signature verified by a valid qualified certificate is equivalent to a declaration of intent made in standard written form.

17 Resolution of the Supreme Court as of 2.10.2002, Chamber of Labour, Social Security and Social Affairs, III PZP 17/02, Labour Law 2003/9/33, Decisions of the Supreme Court Official Compilation, Chamber of Labour, Social Security and Social Affairs 2003/20/481, Labour and Social Security 2003/11/33, Legal Monitor 2004/4/187-189, Decisions of the Polish Courts 2004/9/464.

$18 \mathrm{~K}$. Jaśkowski, op. cit.

19 Article 60 of the Civil Code: Subject to the exceptions provided for in the law, the intention of a person performing a legal act may be expressed by any behavior of that person which manifests his intention sufficiently, including the intent being expressed in electronic form (declaration of intent).

20 Act on Electronic Signatures dated 18 September 2001, "Journal of Laws" 2001, No. 130, item 1450 as amended.

21 J. Janowski, Elektroniczna postać a elektroniczna forma oświadczenia woli, [in:] Podpis elektroniczny w obrocie prawnym, WKP 2007, p. 284. 
by communicating that he/she accepts the employer's employment offer ${ }^{22}$. In particular, he/she may submit the declaration electronically. The provision of Art. 60 of the Civil Code states that the intent of a person aiming at producing legal effects may be expressed in any way that is understood by the recipient ${ }^{23}$, but only when the law does not lay down farther-reaching requirements for the declaration of intent in respect of the given legal transaction.

It follows that the conduct of the person submitting a declaration of intent must be clear to other people - particularly to its recipients - i.e. it must be a meaningful sign (an act of communication) ${ }^{24}$. It is not important, however, what means of communication are used by the person submitting the declaration, if such means are subject to certain rules. Therefore, ,electromagnetic waves connected with the movement of electrons or light waves may be a means of communication, provided that they are encoded in a way that allows to establish the content of the messages and its sender" 25 . In contemporary technology such waves are data media in computer connections, while information communicated by electronic media cannot be denied legal relevance ${ }^{26}$.

Thus, declarations of any future parties to employment contract may be made electronically and if both parties wish to establish an employment relationship, they may do so by submitting the declarations through electronic media. In order to specify whether the parties have actually concluded an employment contract or any other kind of agreement, e.g. a civil law contract, it takes to determine the type of work to be performed - whether the person has agreed to perform work individually, in a continuous manner and pursuant to the recommendations of the employer and whether the work shall be performed in the place and time specified by the employer, and if yes, the contract so concluded will be regarded as an employment contract. The intent and object of the contract concluded by the parties are relevant, too, and so are employee subordination and employment stability ${ }^{27}$.

There is therefore no doubt that the form of employment contract has no influence on the employment relationship. Valid and effective may be an oral, or even implied contract, i.e. by letting the employee do his/her job. It is essential however that in order to establish an employment relationship, the employer must undertake, at least factually (without preserving the required form), to engage

22 R. Sadlik, Zawarcie umowy o pracę w sposób dorozumiany, MPP 2011, No. 9, p. 470.

23 S. Dmowski, S. Rudnicki, Komentarz do Kodeksu cywilnego. Księga pierwsza. Czesść ogólna, Warszawa 2004, p. 249.

24 Z. Radwański, Elektroniczna forma czynności prawnej, MoPr 2001, No. 22, p. 1110.

25 E. Diakowska, Miejsce zawarcia umowy elektronicznej, CBKE - e-bulletin, p. 4, http:// cbke.prawo. uni.wroc.pl/files/ebiuletyn/Miejsce_zawarcia.pdf [10.02.2014].

26 Z. Radwański, Prawo cywilne - część ogólna. t. 2. System Prawa Prywatnego, Warszawa 2002, p. 164-165.

27 R. Sadlik, op. cit., p. 471. 
the employee for a compensation ${ }^{28}$. The notion of legal transaction concluded impliedly refers just to the form (manner) of expressing one's will. Whether the declaration comes from a person who can effectively make it is a different question. Therefore, an employment contract may only be concluded implicitly if, on making the declaration, the employer is duly represented by a person authorised to conclude employment contracts ${ }^{29}$. The same goes for making declarations of intent electronically - declarations of intent of the parties may be made on their behalf, but in order to verify whether an employment contract has been concluded it takes to ascertain whether the declaration to employ the employee was made by the employer and whether the type of work has been specified in the contract (which is an essential element of employment contract). When it is impossible to ascertain the type of work to be performed, the transaction concluded cannot be deemed to be an employment contract ${ }^{30}$.

\section{The term "electronic media"}

At this point it feels right to elucidate the term "electronic media". It has been regulated in the Act on Rendering Electronic Services of 18 July $2002^{31}$. Pursuant to the provision of Art. 2 section 5 of the foregoing Act, electronic media are any and all technical solutions, including ICT equipment and matching software, which enable remote communication between individuals using data transmission between ICT systems, in particular electronic mail. The ICT system described in the foregoing Act realises two purposes: data processing (like IT systems) and remote data transmission between data processing systems (like telecommunication systems $)^{32}$. Essentially, such technical solutions, i.e. electronic communication media, are to enable individual remote communication.

By definition, electronic media are used for individual electronic data transmission $^{33}$. In the judgment of 5 December 2006 the Administrative Court decided that facsimile machine cannot be considered an electronic medium ${ }^{34}$. On the other hand, mobile telephone is a means of electronic communication, but only in respect of data transmission by SMS, MMS, WAP or e-mail ${ }^{35}$.

${ }_{28}$ Specified by the Supreme Court in the judgment of 18.6.2007, II PK 341/06, MoPr, No. 12/2007, p. 647.

29 Judgment of the Supreme Court of 5.12.2002 r., I PKN 629/01, OSNP, No. 11/2004, item 194.

${ }^{30}$ K. Jaśkowski, op. cit.

31 Act on Rendering Electronic Services of 18 July 2002, "Journal of Laws" 2002, No. 144, item 1204 as amended.

32 A. Sobczyk, Telepraca w prawie polskim, WKP 2009, p. 32.

33 J. Janowski, Elektroniczny obrót prawny, WKP 2009, p. 79.

34 Judgment of the Administrative Court of 5.12.2006, III SA/Wa 1836/06, Lex, No. 295045.

35 J. Janowski, op. cit., p. 79. 
The primary, though not exclusive, medium through which employment contracts nay be concluded is the Internet. It offers various forms of individual electronic communication, in particular by electronic mail, but also via websites, online chats, IRC ${ }^{36}$, instant messaging (e.g. Gadu-Gadu) ${ }^{37}$.

\section{Declaring intent in electronic communication}

Out of the afore-mentioned electronic communication techniques two appear to be particularly fit and potentially universal for concluding employment contracts: websites and electronic mail (or other individual means of remote communication). The doctrine emphasises that concluding contracts with the use of one of the foregoing techniques is different from the conventional form to the extent that supports the distinction between them within Art. $66^{138}$ of the Civil Code ${ }^{39}$ (which regulates matters pertaining to the submission of offers by means of the foregoing techniques). Inasmuch concluding contracts through websites takes place on-line, e-mails and SMS and MMS texts are characterised by "passive" access to the net, hence in this mode contracts are concluded off-line.

Therefore, considering the options of concluding an employment contract via electronic media, it is recommendable to specify the kind of media to be used. Before a contract is actually concluded, the text of the declaration to be made electronically must be entered into the electronic medium so that the recipient may read it.

${ }^{36}$ IRC (Internet Relay Chat) - one of the oldest online services that allows communication on various channels, also a private one with another person. The chat process works on a client/ server model of networking, i.e. it is a group of connected servers and programs - clients. IRC offers communication on various channels. Some of them are constant, others may be opened by a user, who wants to communicate with another person. The screen displays messages sent by people communicating on a particular channel. Such messages are displayed immediately after they are sent to the server and in the same order. Therefore the user gets the feeling of a real conversation of people sitting in the same room.

37 Instant Messenger - a computer program that allows for an immediate message transfer (instant communication) between two or more computers through a computer network, usually the Internet. It differs from a standard e-mail in that the user also receives information about the accessibility of other users, which gives the feeling of a direct conversation.

${ }_{38}$ Article $66^{1}$ of the Civil Code: section 1 An offer made electronically binds the of error if the other party immediately confirms receipt thereof. section 3 The provision of section 2 applies accordingly it an entrepreneur invites the other party to enter into negotiations, make offers or execute contracts in any other way. section 4 The provisions of section 1-3 do not apply to the execution of contracts by electronic mail or similar means of individual remote communication. Neither do they apply in relations between entrepreneurs if the parties so agree.

39 D. Karwala, Zawieranie umów elektronicznych w trybie ofertowym - uwagi na tle art. $66^{1}$ KC, [in:] J. Gołaczyński, Prawo Mediów Elektronicznych, "Legalis" and its literature. 
Pursuant to the judgment of the Supreme Court as of 16 May $2003^{40}$, a declaration of intent in electronic form, as described in Art. 61 section $2^{41}$ of the Civil Code, is made by the text of the declaration being correctly entered into an electronic device (computer) of the sender and then transmitted via the Internet using the software tools that enable remote data transmission and receipt through the server of the telecommunication service provider (Internet service provider) and immediately accessible to the recipient - owner of an email account.

At that, whether the declaration so made has been delivered effectively depends on whether the recipient can read it normally, without any extra expenditures and effort $^{42}$. In principle, the risk of the declaration not being delivered in due time to the recipient lies with the declarant. Also, it is important to find out what happens in a situation when the declaration that has gone through the addressee's interface cannot be read thereby due to some technical problems, e.g. no appropriate software, software failure, wrong format of the declaration, or file damage during its transfer to the recipient. In such cases, the declarant will have the evidence confirming that the file has been sent and, therefore, as suggested by E. Diakows$\mathrm{ka}^{43}$, the recipient will have to prove that even though the declaration was entered into the electronic communication medium the addressee was unable to read its text. In either situation, it should be considered whether the recipient was able to read the declaration of intent. If not, the declaration is deemed not to have been effectively delivered. Therefore, it cannot be assumed that the declaration was made effectively, if, even though was entered into the electronic communication medium, but in a form that actually prevented the recipient from reading its text ${ }^{44}$. In the foregoing situations the risk lies with the recipient only when the obstacles to reading the text of the declaration are on his side, e.g. for reason of the addressee's computer being "infected" 45 or out of order, of which the sender is unaware and only receives information that the file has reached the recipient ${ }^{46}$.

To sum up the foregoing considerations, for the purpose of judging whether an employment contract has actually been concluded via electronic media, it is important to ascertain whether the declaration was made appropriately, i.e. whether it was duly delivered, considering the specific nature of making and transmitting such declarations via electronic communication media.

40 Judgment of the Supreme Court of 16.05.2003,I CKN 384/01, Lex, No. 358821.

${ }^{41}$ Article 61 section 2 of the Civil Code: A declaration of intent expressed in electronic form is deemed made to another person at the time it is introduced to the means of electronic communication in such a manner that the person could have read its content.

42 J. Barta, R. Markiewicz, Internet a prawo, Kraków 1998, p. 50.

${ }^{43}$ E. Diakowska, Miejsce zawarcia umowy elektronicznej, CBKE - e-bulletin, p. 13, http:// cbke. prawo.uni.wroc.pl/files/ebiuletyn/Miejsce_zawarcia.pdf [10.02.2014].

44 W. Dubis, Elektroniczne oświadczenie woli, [in:] J. Gołaczyński (ed.), Umowy elektroniczne w obrocie gospodarczym, Warszawa 2005, p. 32.

45 M. Świerczyński, Prawo Internetu, Warszawa 2004, p. 91.

46 X. Konarski, Internet i prawo w praktyce, Warszawa 2002, p. 78. 


\section{Concluding employment contract through websites}

To conclude a contract via a website it usually takes to fill in the form available on that website and send it on-line. With this kind of contracts it is decisive whether doing so is regarded as the addressee's response to and acceptance of the offer, or just an invitation to negotiations, i.e. making an offer. At this point it needs to be emphasised that in terms of the Civil Code regulations, which apply accordingly on concluding an employment contract, a contract may be concluded by way of offer and acceptance, negotiations, as well as auction or tender. For the purpose of concluding employment contracts the first two modes are particularly important.

An agreement is concluded through negotiations when the parties agree to all the contractual provisions by negotiating the same, and by way of offer and acceptance, when the offer is accepted.

It goes without saying that the legal nature of the form available on the website may be determined by the owner of the website. It may clearly state that by filling in and sending the form the offeree (candidate) has responded to the offer of concluding an employment contract presented by the offeror (employer). However, a website is comparable to a prospectus, a form of an invitation to negotiations, and, therefore, it should rather be governed accordingly by the Civil Code regulation which indicates that announcements, advertisements, price lists and other information presented to the world at large or to definite persons, in case of any doubt are considered not to be an offer, but an invitation to negotiations. This would rather suggest that the filling in and sending the "employment contract" form on-line is the beginning of employment negotiations with the future employer ${ }^{47}$.

In terms of Art. $66^{1}$ section 1 of the Civil Code, whether an offer is binding is regulated differently and relative to the electronic communication medium used to make it. When an agreement is concluded through a website, i.e. on-line, the addressee is required to immediately confirm the receipt of the offer (Art. $66^{1}$ section 1 of the Civil Code), while when e-mail is used (off-line), Art. 61 section 2 of the Civil Code ${ }^{48}$ applies.

Also, employment contract may be concluded implicitly, or by conduct, e.g. by allowing the candidate to work. Therefore, when concluding an employment

47 See e.g.: J. Barta, R. Markiewicz, op. cit., p. 59; R. Golat, Internet - aspekty prawne, Warszawa 2003, p. 66; D. Kasprzycki, Handel elektroniczny. Etap przedofertowy, [in:] J. Barta, R. Markiewicz (ed.), Handel elektroniczny. Problemy prawne, Kraków 2004, p. 51; D. Szostek, Czynność prawna a środki komunikacji elektronicznej, Zakamycze 2004, p. 147.

${ }_{48}$ M. Wiktorczyk, Zawieranie umów przez sieć Internet, CBKE - e-bulletin, p. 5, http:// cbke.prawo.uni.wroc.pl/files/ebiuletyn/Zawieranie $\% 20$ umow $\% 20$ przez $\% 20$ siec $\% 20$ Internet.pdf [10.02.2014]. 
contract through electronic communication media it takes to determine when and where such a contract is concluded, because any doubts about the legal status of, e.g. the on-line application form may lead to the conclusion that the contract was in fact concluded by conduct only, after the beginning of employment, as previously the parties had only used the website to negotiate employment, or exchange information about the possible future employment ${ }^{49}$.

\section{Concluding contracts through e-mail or similar means of remote individual communication}

Essentially, sending a signed employment contract by e-mail does not cause the same to meet the requirements for the conventional written form of the contract. Such document may only increase the likelihood that the contract has been concluded. In case of a dispute, the obligation to prove that the employment contract has been concluded falls upon the claimant (Art. 6 of the Civil Code and Art. 232 of the Code of Civil Procedure). One obvious exception to this rule is when the declarations of intent are made in electronic form and affixed with safe electronic signature that can be verified with valid qualified certificate. Such declarations are equivalent to declarations of intent made in writing.

In general, however, e-mail messages are not affixed with safe electronic signature verified with valid qualified certificate. Usually, these messages are accessible to the recipient almost immediately after being sent (in normal use of electronic mail). It is also possible to scan the signed declarations of the parties and send them by e-mail. The scan of such declarations only contains electronic reproductions of the signatures, therefore the requirements for the conventional written form are not met. Furthermore, declarations submitted by e-mail may raise some doubts whether the declarant is the sender of the e-mail. It is essential to verify the person that makes the declaration. If a person is employed on an employment contract not abiding by the written form requirement, the employer is required to confirm in writing all the arrangements regarding the parties, job description and conditions at the latest on the employment commencement date.

To sum up, employment contract may be concluded through electronic communication media, however, on a case-by-case basis it should be ascertained whether the declarations of the parties were actually made, whether they were correctly entered into the electronic communication medium so that the addre-

49 See also judgment of the Supreme Court of 5.11.2003, I PK 633/02, OSNP 2004, No. 20, item 346, based on which: even when an employment agreement turns to be invalid, i.e. did not create an obligation on the date of signing it, such obligations arise when an employee is permitted to work pursuant to the conditions of the agreement. 
ssee was able to read them, as it is only when they are affixed with safe electronic signature verified with valid qualified certificate the written form requirement is met (assuming, of course, that it is the "written" form within Art. 29 section 2 of the Labour Code, i.e. the conventional written form of the contract). Failure to affix a "safe" signature on the declarations of intent will cause the employer to have to confirm in writing, at the latest on the employment commencement date, the arrangements regarding the parties, job description and conditions.

Additionally, upon concluding employment contract through electronic communication media it is important to determine the actual intent of the parties as well as the nature of the agreement. However, if the parties are willing to establish the employment relationship, they may make their declarations by any means, including electronic communication media. Considering the rate of technological development and growing popularity of electronic communication media, it seems that their use for the purpose of concluding contracts will be more and more common, too. Which is a good reason to define the legal effects of this manner of concluding employment contracts, as well as develop a uniform interpretation of the term "in writing" within Art. 29 section 2 of the Labour Code. 